\title{
A Facile Electrochemical Sensor Labeled by Ferrocenoyl Cysteine Conjugate for the Detection of Nitrite in Pickle Juice
}

\author{
Xiao-Zhen Feng ${ }^{1,2}$, Annaleizle Ferranco ${ }^{3}$, Xiaorui $\mathrm{Su}^{2}$, Zhencheng Chen ${ }^{2}$, Zhiliang Jiang ${ }^{1, *}$ and \\ Guo-Cheng Han 2,*iD \\ 1 Key Laboratory of Ecology of Rare and Endangered Species and Environmental Protection (Guangxi Normal \\ University), Ministry Education, Guangxi Key Laboratory of Environmental Pollution Control Theory and \\ Technology, Guilin 541004, China; fxz97118@guet.edu.cn \\ 2 School of Life and Environmental Sciences, Guilin University of Electronic Technology, Guilin 541004, China; \\ 18137725539@163.com (X.S.); chenzhcheng@163.com (Z.C.) \\ 3 Department of Physical and Environmental Sciences, University of Toronto Scarborough, Toronto, \\ ON M1C 1A4, Canada; annaleizle.ferranco@gmail.com \\ * Correspondence: zljiang@mailbox.gxnu.edu.cn (Z.J.); hangc81@guet.edu.cn (G.-C.H.); \\ Tel.: +86-773-584-6141 (Z.J.); +86-773-221-7609 (G.-C.H.)
}

Received: 5 December 2018; Accepted: 8 January 2019; Published: 11 January 2019

check for updates

\begin{abstract}
Simple and facile electrochemical sensors for nitrite detection were fabricated by directly depositing ferrocenoyl cysteine conjugates $\mathrm{Fc}[\mathrm{CO}-\mathrm{Cys}(\mathrm{Trt})-\mathrm{OMe}]_{2}\left[\mathrm{Fc}(\mathrm{Cys})_{2}\right]$ or Fc[CO-Glu-Cys-Gly-OH] [Fc-ECG] on screen-printed electrodes (SPEs). The modified carbon electrodes were characterized by scanning electron microscopy (SEM), cyclic voltammetry (CV) and differential pulse voltammetry (DPV). Results indicated that Fc-ECG/SPE sensor showed enhanced current response and a lower overpotential than $\mathrm{Fc}(\mathrm{Cys})_{2} / \mathrm{SPE}$ sensor for nitrite detection. Optimal operating conditions were estimated for nitrite detection by DPV. The concentration of nitrite showed a good linear relationship with the current response in the range of $1.0-50 \mu \mathrm{mol} \cdot \mathrm{L}^{-1}$ and with $0.3 \mu \mathrm{mol} \cdot \mathrm{L}^{-1}$ as the concentration for limit of detection. There were no interferences from most common ions. The development of this electrochemical sensor was used for nitrite detection in pickled juice with a R.S.D. lower than $2.1 \%$ and average recovery lower than $101.5 \%$, which indicated that disposable electrochemical sensor system can be applied for rapid and precise nitrite detection in foods.
\end{abstract}

Keywords: electrochemical sensor; nitrite; ferrocenoyl cysteine; screen-printed electrode; disposable

\section{Introduction}

Nitrite is a good antimicrobial agent for the prevention of fresh meat and fish products from natural degradation in food preservation [1]. However, nitrite can interact with amines or the amino acids of proteins, especially in cured meat, to form toxic and carcinogenic nitrosamines that may lead to gastrointestinal tumors and stomach cancer [2]. Moreover, high concentrations of nitrite in the human body increases the irreversible oxidation of hemoglobin to methemoglobin, which limits the oxygen loading ability of the blood and is hazardous to human health [3]. It is also a big world problem that nitrite contamination of drinking water in reservoirs and aquifers directly influence human health, which are contributed by agricultural fertilizers and manure. Consequently, accurate quantitative analysis and effective removal of nitrite is of great importance for human health and environmental protection [4,5].

Several methods have been employed for nitrite detection, such as chromatography [6], spectrophotometry [7], capillary electrophoresis [8], chemiluminescence [9], colorimetry [10], fluorescence 
spectroscopy [11], high-performance liquid chromatography [12], and electrochemical methods [13,14]. Electrochemical methods are very popular because of their simple operation, sensitive response and fast detection [15]. The main mechanism for nitrite electrochemical detection is based on reduction or oxidation of nitrite on the electrodes [16]. The oxidation of nitrite on bare electrodes often occurs at high potentials and the electrodes can be poisoned by the species produced in the electrochemical reaction [17]. An appropriate catalyst-modified electrode provides an effective method to lower nitrite potentials $[18,19]$. Moreover, an optimal mediator may improve the sensitivity and selectivity of modified electrodes for nitrite detection.

It should be mentioned that the rapid growth of organometallic chemistry has benefitted from the discovery of ferrocene and its derivatives [20]. The most important application of ferrocene and its derivatives is that they can be used as electrochemical probes for detection of a wide range of biomolecules with great stability in aqueous media. The well-characterized one-electron reversible oxidation wave of ferrocene contributes to the development of electrochemical sensors [21-23]. Moreover, ferrocene derivatives are suitable recognition receptors, and interact with various enzymes, DNA, RNA and other macromolecular substances in cells, which can be monitored by their good redox properties [24-26].

In this study, simple and facile electrochemical sensors were developed by directly depositing ferrocene derivatives $\mathrm{Fc}_{\mathrm{C}}[\mathrm{CO}-\mathrm{Cys}(\mathrm{Trt})-\mathrm{OMe}]_{2}\left[\mathrm{Fc}(\mathrm{Cys})_{2}\right]$ or $\mathrm{Fc}_{\mathrm{C}}[\mathrm{CO}-\mathrm{Glu}-\mathrm{Cys}-\mathrm{Gly}-\mathrm{OH}]$ [Fc-ECG] on screen-printed electrodes (SPEs). Two ferrocenoyl cysteine conjugate sensors, $\mathrm{Fc}(\mathrm{Cys})_{2} / \mathrm{SPE}$ and Fc-ECG/SPE, were successfully prepared and characterized. However, Fc-ECG/SPE sensor that was used for nitrite detection showed an enhanced current response and a lower overpotential than $\mathrm{Fc}(\mathrm{Cys})_{2} / \mathrm{SPE}$ sensor, which could be used as an effective sensor for the assessment of nitrite concentration. Moreover, the proposed method was also used to determine the presence of nitrite in pickled juice with satisfactory results.

\section{Materials and Methods}

\subsection{Chemicals and Reagents}

Sodium nitrite was purchased from Aladdin Reagent Co. Ltd. (Shanghai, China). $\mathrm{Fc}_{\mathrm{C}}[\mathrm{CO}-\mathrm{Cys}(\mathrm{Trt})-\mathrm{OMe}]_{2}$ (abbreviated as $\left.\mathrm{Fc}_{\mathrm{C}}(\mathrm{Cys})_{2}\right)$ was synthesized according to [27]. Fc[CO-Glu-Cys-Gly-OH] (Fc-ECG) was purchased from Shanghai Chang Xi Biotechnology Co. Ltd. (Shanghai, China). Disodium hydrogen phosphate $\left(\mathrm{Na}_{2} \mathrm{HPO}_{4}\right)$, sodium dihydrogen phosphate dehydrate $\left(\mathrm{NaH}_{2} \mathrm{PO}_{4}\right), \mathrm{H}_{3} \mathrm{PO}_{4}$ and $\mathrm{NaOH}$ were purchased from Guilin Xinpeng Chemical Reagent Sales Department (Guilin, China). Pickled mustard was purchased from local supermarket, the pickle juice was diluted directly by PBS for test after centrifugal separation from pickled mustard. All other reagents were of analytical grade and used without further purification. All aqueous solutions were prepared with Milli-Q water (Millipore, Burlington, MA, USA).

\subsection{Preparation of $F c(C y s)_{2} / S P E$ and $F c-E C G / S P E$ Electrochemical Sensors}

At first, $0.5 \mathrm{mmol} \cdot \mathrm{L}^{-1}$ of $\mathrm{Fc}_{\mathrm{C}}(\mathrm{Cys})_{2}$ stock solution was prepared by dissolving $\mathrm{Fc}_{\mathrm{C}}(\mathrm{Cys})_{2}$ in acetonitrile solvent. $0.5 \mathrm{mmol} \cdot \mathrm{L}^{-1} \mathrm{Fc}$-ECG stock solution was prepared by dissolving Fc-ECG in Milli-Q water. $10.0 \mathrm{mmol} \cdot \mathrm{L}^{-1}$ nitrite stock solution was prepared by dissolving sodium nitrite in Milli-Q water. $0.1 \mathrm{~mol} \cdot \mathrm{L}^{-1}$ phosphate buffer solutions (PBS) with various $\mathrm{pH}$ values were used as the supporting electrolyte, and prepared by mixing $0.1 \mathrm{~mol} \cdot \mathrm{L}^{-1} \mathrm{NaH}_{2} \mathrm{PO}_{4}$ and $0.1 \mathrm{~mol} \cdot \mathrm{L}^{-1} \mathrm{Na}_{2} \mathrm{HPO}_{4}$. The $\mathrm{pH}$ value of PBS was adjusted by $0.1 \mathrm{~mol} \cdot \mathrm{L}^{-1}$ of $\mathrm{H}_{3} \mathrm{PO}_{4}$ and $0.1 \mathrm{~mol} \cdot \mathrm{L}^{-1}$ of $\mathrm{NaOH}$ solution. The prepared solutions were stored in a refrigerator at $4{ }^{\circ} \mathrm{C}$. All stock solutions were diluted to the appropriate concentration before experiment, including separated pickle juice directly diluted by PBS. Then, the fabrication of the sensors were carried out by depositing either electroactive material $\mathrm{Fc}(\mathrm{Cys})_{2}$ or $\mathrm{Fc}-\mathrm{ECG}$ onto the surface of the SPE for $30 \mathrm{~min}$ until dry, and electrochemical sensors 
of $\mathrm{Fc}(\mathrm{Cys})_{2}$ /SPE and Fc-ECG/SPE for nitrite detection by DPV were prepared. The preparation of electrochemical sensor of Fc-ECG/SPE for nitrite detection by DPV is simple and described in Figure 1.

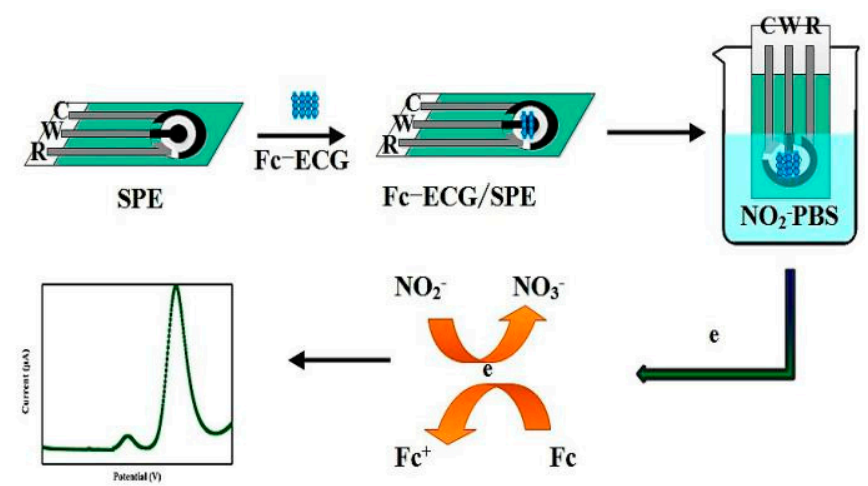

Figure 1. Fabrication of Fc-ECG/SPE electrochemical sensor for nitrite detection by DPV.

\subsection{Apparatus and Electrochemical Performance}

Morphologies of the electrochemical sensors were analyzed by field emission scanning electron microscope produced from Hitachi High-Technologies Corporation (Tokyo, Japan) at $3 \mathrm{kV}$ and $10,100 \mathrm{nA}$ with the working distance of $6000 \mu \mathrm{m}$.

The electrochemical analyses were carried out using screen-printed electrodes that were provided by Nanjing Yunyou Biotechnology Co. Ltd. (Nanjing, China). One modified carbon paste electrode was used as the working electrode $(\varphi 3 \mathrm{~mm})$, another carbon paste electrode as the auxiliary electrode and $\mathrm{Ag} / \mathrm{AgCl}$ electrode as the reference electrode in an enclosed faraday cage, which were connected to a CHI660E electrochemical workstation (Shanghai Chenhua Instrument Co., Ltd., Shanghai, China). For the cyclic voltammetry $(\mathrm{CV})$ experiments, all measurements were carried out with a scan rate of $100 \mathrm{mV} \cdot \mathrm{s}^{-1}$ in range of $-400-+1200 \mathrm{mV}$ in $0.1 \mathrm{~mol} \cdot \mathrm{L}^{-1}$ phosphate buffer (PBS) as the supporting electrolyte. DPVs were performed in $0.1 \mathrm{~mol} \cdot \mathrm{L}^{-1} \mathrm{PBS}$ with a pulse amplitude of $50 \mathrm{mV}$ in range of $-400-+1200 \mathrm{mV}$.

\section{Results and Discussion}

\subsection{Characterization and Electrochemical Properties of Modified Electrodes}

After directly dropping electroactive material ferrocenoyl cysteine conjugates of $\mathrm{Fc}(\mathrm{Cys})_{2}$ or Fc-ECG SEM was employed to characterize the electrode surface in order to verify the successful electrode modification. Figure 2 shows the SEM images of different materials modified SPEs.

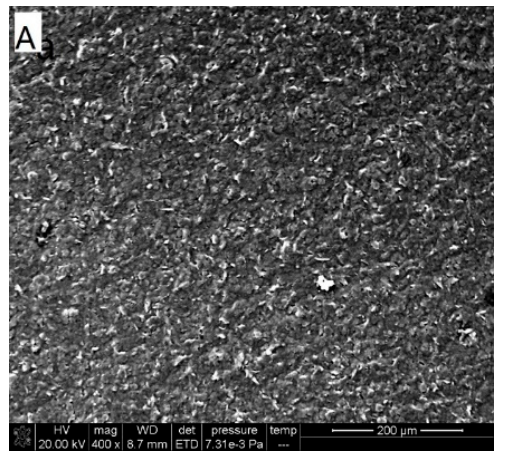

(A)

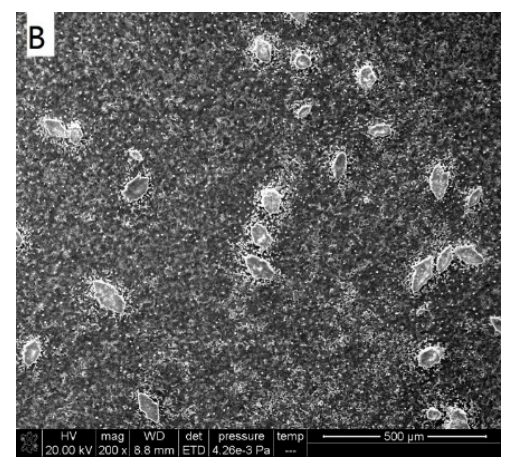

(B)

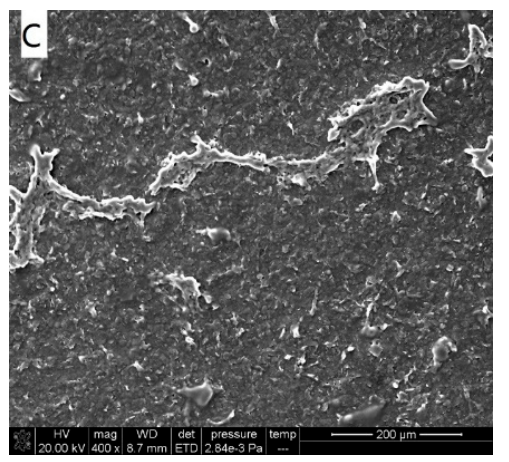

(C)

Figure 2. SEM images of different materials modified SPEs ((A): naked SPE, (B): $\mathrm{Fc}(\mathrm{Cys})_{2} / \mathrm{SPE}$; (C): Fc-ECG/SPE). 
Figure 2A presents a number of carbon particles on the surface of naked SPE with rough amorphous carbon morphology. After depositing eitherelectroactive material $\mathrm{Fc}(\mathrm{Cys})_{2}$ or $\mathrm{Fc}-\mathrm{ECG}$, the surface of SPE became smooth (Figure 2B,C), leaf spot and spray zones were observed on the surface of electrode, respectively. These figures confirmed that electroactive materials were coated onto the SPE surface successfully.

The electro-active response property is important, and should be investigated after morphology characterization. Figure 3 shows CV (A) and DPV (B) curves for different material modified SPEs in PBS ( $\mathrm{pH} 7.0)$, respectively.

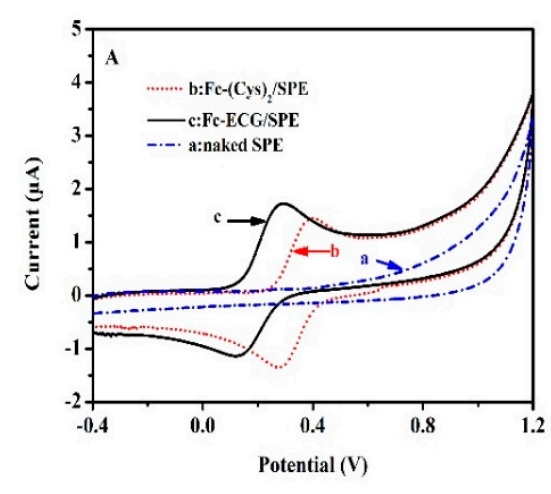

(A)

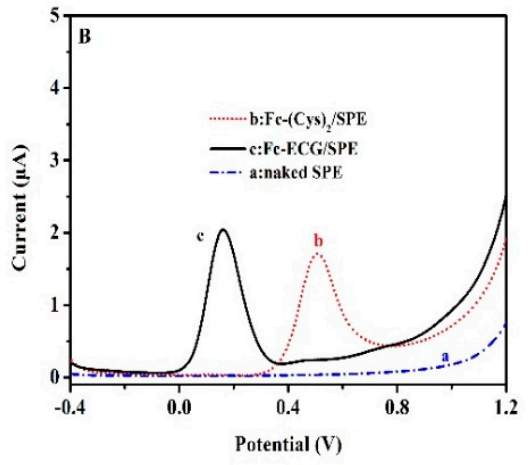

(B)

Figure 3. CV (A) and DPV (B) curves for different materials modified SPEs in $0.1 \mathrm{~mol} \cdot \mathrm{L}^{-1} \mathrm{PBS}(\mathrm{pH} 7.0)$ (a: naked SPE, b: $\mathrm{Fc}_{\mathrm{C}}(\mathrm{Cys})_{2} / \mathrm{SPE}$; $\mathrm{F}$ F-ECG/SPE).

As can be seen in Figure 3A, curve a was a straight line and there was no electrocatalytic response from the naked SPE in PBS. After depositing $\mathrm{Fc}_{\mathrm{C}}(\mathrm{Cys})_{2}$ or Fc-ECG onto the surface of SPE, electro-catalytic response of two modified SPEs were observed in curves $b$ and c, respectively. $\mathrm{Fc}(\mathrm{Cys})_{2} / \mathrm{SPE}$ showed redox peaks at 0.40 and $0.28 \mathrm{~V}$ with $1.45 \mu \mathrm{A}$ and $-1.34 \mu \mathrm{A}$ peak current response, respectively. The Fc-ECG/SPE showed redox peaks at 0.29 and $0.13 \mathrm{~V}$ with 1.71 and $-1.12 \mu \mathrm{A}$ peak current response, correspondingly. The electrochemical process indicated a quasi-reversible reaction, for both $\mathrm{Fc}(\mathrm{Cys})_{2} / \mathrm{SPE}$ and $\mathrm{Fc}-\mathrm{ECG} / \mathrm{SPE}$. Similar results were observed from DPV signals at 0.5 and $0.16 \mathrm{~V}$ with peak current response of 1.73 and $2.06 \mu \mathrm{A}$, as shown in Figure 3B. All the results illustrated the successful modification of the electrodes by different active electrochemical materials, which was consistent with the SEM results.

\subsection{Electrochemical Behavior of Nitrite on the Modified Electrode}

After successful characterization of electrochemical sensors, the actual application was investigated. Figure 4 shows CV (A) and DPV (B) curves of $100 \mu \mathrm{mol} \cdot \mathrm{L}^{-1}$ of nitrite on different modified electrodes in PBS (pH 7.0).

As can be seen in Figure $4 \mathrm{~A}$, the oxidation potential for nitrite on the naked SPE, $\mathrm{Fc}(\mathrm{Cys})_{2} / \mathrm{SPE}$, and Fc-ECG/SPE was 0.86, 1.06, and $0.95 \mathrm{~V}$ with peak current response of $11.78,4.40$, and $12.79 \mu \mathrm{A}$, respectively. Fc-ECG/SPE can enlarge the current response compared to the naked SPE and $\mathrm{Fc}(\mathrm{Cys})_{2}$ /SPE for nitrite oxidation. Only one unobvious oxidation peak at $0.66 \mathrm{~V}$ was observed in the internal signal of $\mathrm{Fc}(\mathrm{Cys})_{2}$. Fc-ECG showed its identified internal redox peaks at 0.36 and $0.26 \mathrm{~V}$ with a weak peak current response. We can observe the similar results from the DPV experiments as shown in Figure 4B. The oxidation potential for nitrite on the naked SPE and Fc-ECG/SPE were 0.76 and $0.73 \mathrm{~V}$ with peak current of 8.64 and $11.88 \mu \mathrm{A}$ in PBS (pH 7.0), respectively. Fc-ECG/SPE sensor not only can enlarge the current response by $37.5 \%$, but can also lower the oxidation overpotential from 0.76 to $0.73 \mathrm{~V}$. Moreover, it shows the identified internal oxidation peak at $0.32 \mathrm{~V}$ with a weak oxidation peak current response. However, no potential and current response were observed in $\mathrm{Fc}(\mathrm{Cys})_{2}$ and nitrite oxidation on the SPE surface. All the results showed that nitrite oxidation possessed a lower 
overpotential on Fc-ECG/SPE sensor than other modified electrodes, which was also demonstrated by our previous work of hemoglobin catalysis [28]. It presents excellent electrochemical catalytic ability for further study, which can potentially be used for nitrite detection.

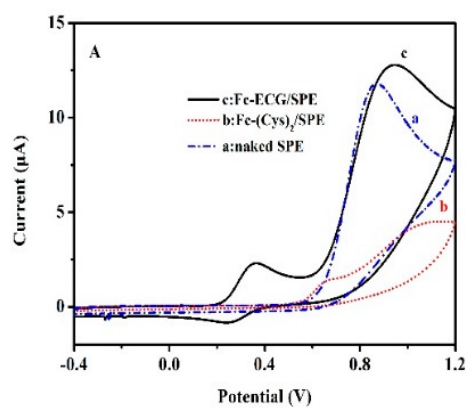

(A)

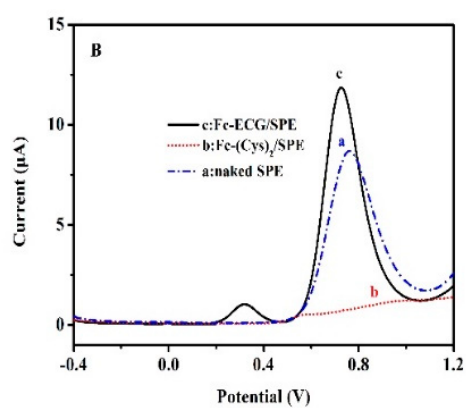

(B)

Figure 4. CV (A) and DPV (B) curves of different materials modified SPEs for detection of $100 \mu \mathrm{mol} \cdot \mathrm{L}^{-1}$ nitrite in $0.1 \mathrm{~mol} \cdot \mathrm{L}^{-1} \mathrm{PBS}$ ( $\mathrm{pH} 7.0$ ) (a: naked SPE, b: Fc(Cys) $)_{2} / \mathrm{SPE}$; $\mathrm{c}$ Fc-ECG/SPE).

\subsection{Optimization of Experimental Parameters}

The optimization of experimental parameters, including detection temperature, $\mathrm{pH}$ of phosphate buffer solution, drop volume of electroactive material and deposition time, wereinvestigated. Figure $5 \mathrm{~A}$ shows the DPV curves for nitrite oxidation on Fc-ECG/SPE sensor at different temperatures. Figure 5B,C show the current response of different $\mathrm{pH}$ values and different drop volume of Fc-ECG electroactive material. Figure 4D expresses the current response of reaction time on the electrode surface for nitrite oxidation.

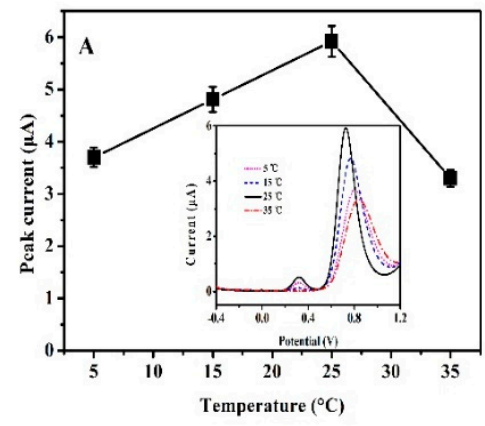

(A)

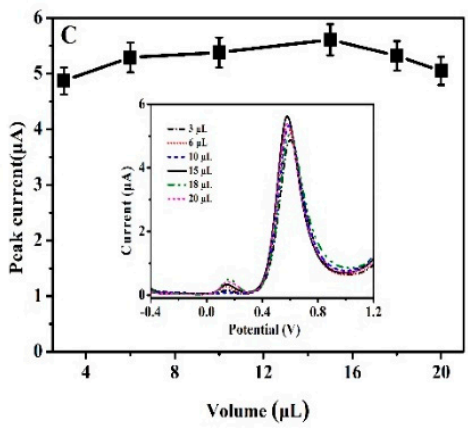

(C)

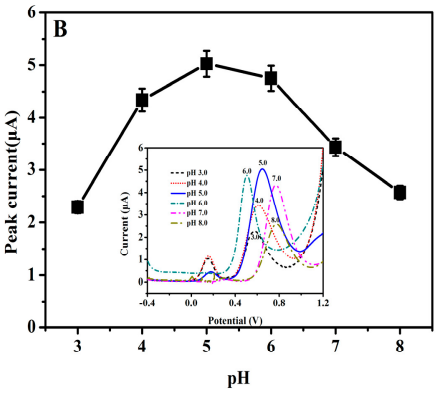

(B)

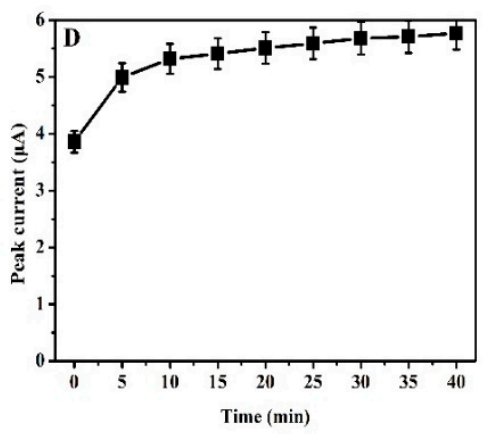

(D)

Figure 5. Current responses (The inserts are DPV curves) for $50 \mu \mathrm{mol} \cdot \mathrm{L}^{-1}$ nitrite oxidation on Fc-ECG/SPE sensor in $0.1 \mathrm{~mol} \cdot \mathrm{L}^{-1} \mathrm{PBS}$ with a pulse amplitude of $50 \mathrm{mV}$. (A): $\mathrm{pH} 7.0$, at 5, 15, 25 and $35^{\circ} \mathrm{C}$; (B): pH 3.0, 4.0, 5.0, 6.0, 7.0, 8.0, at $25^{\circ} \mathrm{C}$; (C): pH 5.0, with 3, 6, 10, 15, 18, $20 \mu \mathrm{L}$ of Fc-ECG on electrode at $25^{\circ} \mathrm{C} ;(\mathrm{D})$ : $\mathrm{pH} 5.0$, with $0-40 \mathrm{~min}$ reaction time at $25^{\circ} \mathrm{C}$. 
As can be seen in Figure 5A, the electrochemical sensor of Fc-ECG/SPE displayed good electro-catalytic activities for nitrite at $25{ }^{\circ} \mathrm{C}$, and $25{ }^{\circ} \mathrm{C}$ (room temperature) was chosen for the following experiments. The $\mathrm{pH}$ value is also an important factor for nitrite detection. The Fc-ECG/SPE showed the highest current response of oxidation peaks, and the redox peak shift to a lower potential at $\mathrm{pH}=5.0$, as shown in Figure 5B. The decrease in oxidation peak currents at higher $\mathrm{pH}(>5)$ is due to the shortage of protons, which affects the electrocatalytic oxidation of nitrite. There was also a decrease observed when the $\mathrm{pH}$ of the solution was below $\mathrm{pH}$, indicating that the nitrite ions are not stable in highly acidic environment, the active $\mathrm{NO}_{2}{ }^{-}$species would be converted to $\mathrm{NO}$ and $\mathrm{NO}_{3}{ }^{-}$and form $\mathrm{HNO}_{3}[29]$, which can also affect the catalytic reaction process of nitrite oxidation. It may react as following at a lower $\mathrm{pH}$ :

$$
2 \mathrm{H}^{+}+3 \mathrm{NO}_{2}{ }^{-} \rightarrow 2 \mathrm{NO}+\mathrm{NO}_{3}{ }^{-}+\mathrm{H}_{2} \mathrm{O}
$$

Finally, the maximum oxidation peak current was observed at $\mathrm{pH} 5$, which was selected as the optimal $\mathrm{pH}$ and used for further electrochemical studies. The effects of drop volume of the Fc-ECG electroactive material for nitrite oxidation are shown in Figure 5C. It can be clearly seen that the drop volume of electroactive material showed no obvious effect, and $15 \mu \mathrm{L}$ of Fc-ECG resulted in an adequate sensor response; no further adjustments were made and this volume was for further studies as discussed below. The current increased with increased reaction time, and the current became stable after $20 \mathrm{~min}$, as shown in Figure 5D. Therefore, $20 \mathrm{~min}$ was therefore chosen for electrode reaction time.

\subsection{Nitrite Detection by Electrochemical Sensors and the Sensitivity, Selectivity, Repeatability and Stability Study}

As mentioned above, the primary goal of this work was to prepare electrochemical sensors for detection of nitrite by DPV. Figure 6A shows the DPV curves for different concentrations of nitrite on Fc-ECG/SPE sensor in PBS, with a pulse amplitude of $50 \mathrm{mV}$. Figure 6B-D show the selectivity, repeatability and stability of Fc-ECG/SPE sensor for nitrite oxidation, respectively.

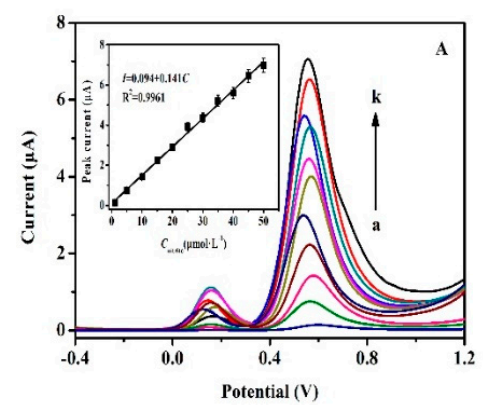

(A)

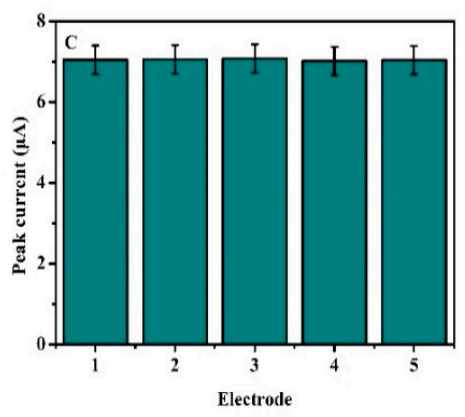

(C)

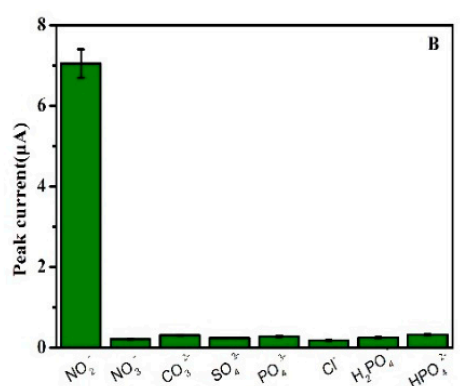

(B)

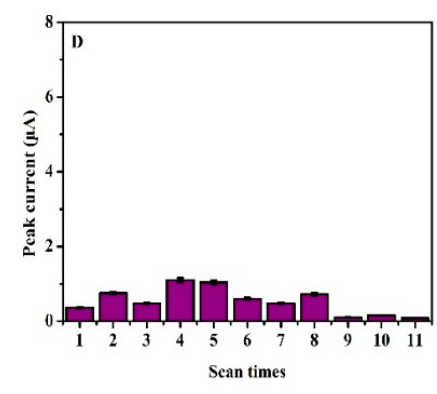

(D)

Figure 6. (A): DPV for different concentrations of nitrite on Fc-ECG/SPE (a-k: 1.0, 5.0, 10, 15, 20, 25, 30, $\left.35,40,45,50 \mu \mathrm{mol} \cdot \mathrm{L}^{-1}\right)$, insert: calibration plot for various concentrations of nitrite; (B): The selectivity of Fc-ECG/SPE sensor for nitrite, $\mathrm{NO}_{3}{ }^{-}, \mathrm{CO}_{3}{ }^{2-}, \mathrm{SO}_{4}{ }^{2-}, \mathrm{PO}_{4}{ }^{3-}, \mathrm{Cl}^{-}, \mathrm{H}_{2} \mathrm{PO}_{4}{ }^{-}$, and $\mathrm{HPO}_{4}{ }^{2-}$, the concentration of each compound is $100 \mu \mathrm{mol} \cdot \mathrm{L}^{-1}$; (C): The repeatability of Fc-ECG/SPE sensor; (D): The stability of Fc-ECG/SPE sensor. 
Under optimal conditions, it was observed that the Fc-ECG/SPE sensor not only showed a characteristic peak at $0.16 \mathrm{~V}$ without a strong peak current response, but also showed the characteristic peak at $0.55 \mathrm{~V}$ versus $\mathrm{Ag} / \mathrm{AgCl}$ electrode for nitrite oxidation (shown in Figure 6A). However, the oxidation peak of nitrite was up at $0.75-0.85 \mathrm{~V}$ on most modified electrodes, as shown in Table 1. Therefore, its oxidation overpotential was reduced deeply with different potential of $210 \mathrm{mV}$ from 0.76 to $0.55 \mathrm{~V}$, because Fc-ECG can act as electron transfer medium and promote charge transfer [28]. These results fully confirmed that Fc-ECG/SPE can be used for nitrite detection based on its excellent electrochemical catalytic ability. The electrochemical oxidation peak currents of nitrite increased with increased concentrations and all followed a linear relationship, as shown in the Figure 6A insert. The peak potentials were kept steady and their calibration curves were linear at concentration ranges of $1.0-50 \mu \mathrm{mol} \cdot \mathrm{L}^{-1}$ for nitrite with detection limits of $0.3 \mu \mathrm{mol} \cdot \mathrm{L}^{-1}$. The linear regression equation for nitrite was expressed as follows: $I=0.094+0.141 C\left(R^{2}=0.9961\right)\left(I: \mu \mathrm{A} ; C: \mu \mathrm{mol} \cdot \mathrm{L}^{-1}\right)$.

As an electrochemical sensor, it is important to evaluate its selectivity and stability for actual application $[30,31]$. To explore the selectivity of the Fc-ECG/SPE, the possible interference factors of nitrite detection were investigated. $100 \mu \mathrm{mol} \cdot \mathrm{L}^{-1}$ of $\mathrm{NO}_{3}{ }^{-}, \mathrm{CO}_{3}{ }^{2-}, \mathrm{SO}_{4}{ }^{2-}, \mathrm{PO}_{4}{ }^{3-}, \mathrm{Cl}^{-}, \mathrm{H}_{2} \mathrm{PO}^{4-}$, and $\mathrm{HPO}_{4}{ }^{2-}$ were used to study the selectivity of the sensor. The different types of interfering agents did not show strong selectivity as shown in Figure 6B, indicating that the sensor possessed good selectivity for the detection of nitrite. A comparison of previously reported electrochemical sensors for nitrite detection with this work is shown in Table 1. Compared with other modified electrodes, although the Fc-ECG/SPE sensor did not show a very wide concentration range and low detection limit, it exhibited low overpotential for nitrite oxidation.

Table 1. Comparison of nitrite detection by different materials modified electrodes with direct electrochemistry.

\begin{tabular}{|c|c|c|c|c|c|}
\hline Modified Electrode & Peak Potential (V) & $\mathrm{pH}$ & $\begin{array}{l}\text { Detection Limit } \\
\quad\left(\mu \mathrm{mol} \cdot \mathrm{L}^{-1}\right)\end{array}$ & $\begin{array}{l}\text { Linear Range } \\
\left(\mu \mathrm{mol} \cdot \mathrm{L}^{-1}\right)\end{array}$ & Reference \\
\hline CR-GO/GCE & $0.8^{\mathrm{a}}$ & 5.0 & 1.0 & $8.9-167$ & [32] \\
\hline $\mathrm{Pd} / \mathrm{SWCNT}$ & $0.75^{\mathrm{a}}$ & 4.0 & 0.25 & $2-238$ & [33] \\
\hline CFO/SPCE & $0.8^{\mathrm{a}}$ & 5.0 & 0.007 & $0.016-1921$ & [29] \\
\hline $\mathrm{Ag} / \mathrm{Cu} / \mathrm{MWNT} / \mathrm{GCE}$ & $0.85^{\mathrm{a}}$ & 7.0 & 0.2 & $1.0-1000$ & [34] \\
\hline Dendrimer/AuNPs/GC & $0.85^{b}$ & 5.0 & 0.2 & $10-5000$ & [35] \\
\hline Ag-PAMAM/GCE & $0.8^{b}$ & 6.0 & 0.4 & $4.0-1440$ & [36] \\
\hline $\mathrm{Hb} / \mathrm{Au} / \mathrm{GACS} / \mathrm{GCE}$ & $0.85^{b}$ & 7.0 & 0.01 & $0.05-1000$ & [37] \\
\hline Fc-ECG/SPE & $0.55^{\mathrm{a}}$ & 5.0 & 0.3 & $1.0-50$ & This work \\
\hline
\end{tabular}

The repeatability was studied by five modified electrodes which were prepared independently. The relative standard deviation (R.S.D) was $0.32 \%$ for $50 \mu \mathrm{mol} \cdot \mathrm{L}^{-1}$ nitrite oxidation by comparing the peak currents in $0.1 \mu \mathrm{mol} \cdot \mathrm{L}^{-1} \mathrm{PBS}$ (pH 5.0) as shown in Figure 6C, indicating its excellent repeatability.

On the other hand, the stability of the Fc-ECG/SPE was also investigated. After modifying the electrode, the Fc-ECG/SPE sensor was used for different concentration nitrite detection. As shown in Figure $6 \mathrm{D}$, there was no obvious change in the peak current intensity even after 11 times scans which were obtained from Figure $6 \mathrm{~A}$ at $0.16 \mathrm{~V}$. Therefore, the proposed electrochemical sensor displayed high selectivity and good stability, and was suitable for nitrite detection.

\subsection{Real Sample Analysis}

To verify the feasibility of Fc-ECG/SPE sensor in practical application, it was applied to detect nitrite concentrations in pickled juice. All the samples were filtrated and diluted with PBS (pH 5.0) to obtain linear concentration range. The analysis data are summarized in Table 2, in which the average recovery of spiked samples was less than $101.5 \%$, and the relative standard deviations (R.S.D.) for the DPV response currents were less than $2.1 \%$, showing the potential practical application of as-prepared sensor in real samples. 
Table 2. Detection of nitrite in pickled juice samples $(n=5)$.

\begin{tabular}{|c|c|c|c|c|c|}
\hline Analyte & $\begin{array}{c}\text { Detected } \\
\left(\mu \mathrm{mol} \cdot \mathrm{L}^{-1}\right)\end{array}$ & $\begin{array}{c}\text { Added } \\
\left(\mu \mathrm{mol} \cdot \mathrm{L}^{-1}\right)\end{array}$ & $\begin{array}{c}\text { Found } \\
\left(\mu \mathrm{mol} \cdot \mathrm{L}^{-1}\right)\end{array}$ & $\begin{array}{c}\text { Average } \\
\text { Recovery (\%) }\end{array}$ & RSD (\%) \\
\hline \multirow{2}{*}{ Pickle juice } & \multirow{2}{*}{$20.0 \pm 0.4$} & 10.0 & $30.4 \pm 0.8$ & 101.4 & 2.1 \\
\hline & & 20.0 & $40.3 \pm 0.9$ & 100.9 & 1.8 \\
\hline
\end{tabular}

\section{Conclusions}

In summary, we have demonstrated a simple strategy for preparing Fc-ECG/SPE sensors for nitrite detection in food samples which were developed by directly depositing the electroactive material Fc-ECG on SPEs by DPV. Electrochemical measurements demonstrated that the Fc-ECG/SPE sensor with its characteristic signal showed improved electrocatalytic performance towards oxidation of nitrite by lowing the overpotential and increasing the peak current, due to the fact that ferrocenoyl cysteine conjugate can act as an electron transfer medium and promote charge transfer. These results demonstrated that Fc-ECG/SPE sensor can be a promising electrochemical sensor for electrocatalytic applications towards nitrite oxidation in the range of $1.0-50 \mu \mathrm{mol} \cdot \mathrm{L}^{-1}$ with $0.3 \mu \mathrm{mol} \cdot \mathrm{L}^{-1}$ limit of detection in pickle juice with a R.S.D. lower than $2.1 \%$ and average recovery lower than $101.5 \%$, which was proved to be applicable for nitrite detection in pickle juice with good selectivity.

Author Contributions: Z.J. and G.-C.H. conceived and designed the experiments; X.-Z.F. and X.S. performed the experiments; Z.C. analyzed the data; G.-C.H. wrote the paper; A.F. revised the language of the paper.

Funding: This research was funded by National Natural Science Foundation of China (No. 61661014, 61627807, 21767004), the Nature Science Foundation of Guangxi Province (No. 2015GXNSFBA139041), Guangxi Middle and Young Teachers Basic Competence Improvement Project (2017KY0189).

Acknowledgments: We appreciate the State Key Laboratory for Chemistry and Molecular Engineering of Medicinal Resources from Guangxi Normal University for providing test for samples.

Conflicts of Interest: The authors declare no conflict of interest.

\section{References}

1. Alahi, M.E.E.; Mukhopadhyay, S.C.; Burkitt, L. Imprinted polymer coated impedimetric nitrate sensor for real-time water quality monitoring. Sens. Actuator B Chem. 2018, 259, 753-761. [CrossRef]

2. Kesavan, S.; Kumar, D.R.; Baynosa, M.L.; Shim, J.J. Potentiodynamic formation of diaminobenzene films on an electrochemically reduced graphene oxide surface: Determination of nitrite in water samples. Mater. Sci. Eng. C Mater. 2018, 85, 97-106. [CrossRef] [PubMed]

3. Arulraj, A.D.; Sundaram, E.; Vasantha, V.S.; Neppolian, B. Polypyrrole with a functionalized multi-walled carbon nanotube hybrid nanocomposite: A new and efficient nitrite sensor. New J. Chem. 2018, 42, 3748-3757. [CrossRef]

4. Liu, J.Y.; Li, X.T.; Batchelor-McAuley, C.; Zhu, G.D.; Compton, R.G. Nitrite-Enhanced Charge Transfer to and from Single Polyaniline Nanotubes. Chem. Eur. J. 2017, 23, 17823-17828. [CrossRef] [PubMed]

5. Zhang, L.; Li, S.B.; Zhang, Z.F.; Tan, L.C.; Pang, H.J.; Ma, H.Y. Facile fabrication of reduced graphene oxide and Keggin-type polyoxometalates nanocomposite film for high performance electrocatalytic oxidation of nitrite. J. Electroanal. Chem. 2017, 807, 97-103. [CrossRef]

6. Yang, H.R.; Xiang, Y.; Guo, X.Y.; Wu, Y.P.; Wen, Y.; Yang, H.F. Diazo-reaction-based SERS substrates for detection of nitrite in saliva. Sens. Actuator B Chem. 2018, 271, 118-121. [CrossRef]

7. Zan, M.H.; Rao, L.; Huang, H.M.; Xie, W.; Zhu, D.M.; Li, L.; Qie, X.W.; Guo, S.S.; Zhao, X.Z.; Liu, W.; et al. A strong green fluorescent nanoprobe for highly sensitive and selective detection of nitrite ions based on phosphorus and nitrogen co-doped carbon quantum dots. Sens. Actuator B Chem. 2018, 262, 555-561. [CrossRef]

8. Wieczorek, M.; Dcbosz, M.; Swit, P.; Wozniakiewicz, A.; Koscielniak, P. Application of gradient ratio flow-injection technique to implementation of the Chemical H-point Standard Addition Method. Talanta 2018, 186, 215-220. [CrossRef] [PubMed] 
9. Mikuska, P.; Capka, L.; Vecera, Z. Aerosol sampler for analysis of fine and ultrafine aerosols. Anal. Chim. Acta 2018, 1020, 123-133. [CrossRef]

10. Zhang, X.X.; Song, Y.Z.; Fang, F.; Wu, Z.Y. Sensitive paper-based analytical device for fast colorimetric detection of nitrite with smartphone. Anal. Bioanal. Chem. 2018, 410, 2665-2669. [CrossRef]

11. Courrol, L.C.; Samad, R.E. Determination of chicken meat contamination by porphyrin fluorescence. J. Lumin. 2018, 199, 67-70. [CrossRef]

12. Khatiwada, R.; Olivares, C.; Abrell, L.; Root, R.A.; Sierra-Alvarez, R.; Field, J.A.; Chorover, J. Oxidation of reduced daughter products from 2,4-dinitroanisole (DNAN) by $\mathrm{Mn}(\mathrm{IV})$ and $\mathrm{Fe}(\mathrm{III})$ oxides. Chemosphere 2018, 201, 790-798. [CrossRef] [PubMed]

13. Salimi, A.; Kurd, M.; Teymourian, H.; Hallaj, R. Highly sensitive electrocatalytic detection of nitrite based on $\mathrm{SiC}$ nanoparticles/amine terminated ionic liquid modified glassy carbon electrode integrated with flow injection analysis. Sens. Actuator B Chem. 2014, 205, 136-142. [CrossRef]

14. Wang, X.Q.; Tan, W.S.; Ji, H.; Liu, F.; Wu, D.T.; Ma, J.F.; Kong, Y. Facile electrosynthesis of nickel hexacyanoferrate/poly(2,6-diaminopyridine) hybrids as highly sensitive nitrite sensor. Sens. Actuator B Chem. 2018, 264, 240-248. [CrossRef]

15. Ghanei-Motlagh, M.; Taher, M.A. A novel electrochemical sensor based on silver/halloysite nanotube/molybdenum disulfide nanocomposite for efficient nitrite sensing. Biosens. Bioelectron. 2018, 109, 279-285. [CrossRef] [PubMed]

16. Manikandan, V.S.; Liu, Z.G.; Chen, A.C. Simultaneous detection of hydrazine, sulfite, and nitrite based on a nanoporous gold microelectrode. J. Electroanal. Chem. 2018, 819, 524-532. [CrossRef]

17. Zhang, Y.; Wen, F.F.; Huan, Z.H.; Tan, J.; Zhou, Z.F.; Yuan, K.C.; Wang, H.G. Nitrogen doped lignocellulose/binary metal sulfide modified electrode: Preparation and application for non-enzymatic ascorbic acid, dopamine and nitrite sensing. J. Electroanal. Chem. 2017, 806, 150-157. [CrossRef]

18. Hu, J.; Guo, F.; Wang, L. Voltammetric determination of nitrite by using a glassy carbon electrode modified with a self-assembled nanocomposite prepared from CdTe quantum dots, cetyltrimethylammonium bromide, chitosan and multiwalled carbon nanotubes. Microchim. Acta 2017, 184, 4637-4646. [CrossRef]

19. Wang, B.B.; Ji, X.P.; Ren, J.J.; Ni, R.X.; Wang, L. Enhanced electrocatalytic activity of graphene-gold nanoparticles hybrids for peroxynitrite electrochemical detection on hemin-based electrode. Bioelectrochemistry 2017, 118, 75-82. [CrossRef]

20. Bizid, S.; Mlika, R.; Said, A.H.; Chemli, M.; Youssoufi, H.K. Functionalization of MWCNTs with Ferrocene-poly(p-phenylene) and Effect on Electrochemical Properties: Application as a Sensing Platform. Electroanalysis 2016, 28, 2533-2542. [CrossRef]

21. Iacob, B.C.; Bodoki, E.; Farcau, C.; Barbu-Tudoran, L.; Oprean, R. Study of the Molecular Recognition Mechanism of an Ultrathin MIP Film-Based Chiral Electrochemical Sensor. Electrochim. Acta 2016, 217, 195-202. [CrossRef]

22. Manibalan, K.; Mani, V.; Chang, P.C.; Huang, C.H.; Huang, S.T.; Marchlewicz, K.; Neethirajan, S. Electrochemical latent redox ratiometric probes for real-time tracking and quantification of endogenous hydrogen sulfide production in living cells. Biosens. Bioelectron. 2017, 96, 233-238. [CrossRef] [PubMed]

23. Alizadeh, T.; Akhoundian, M.; Ganjali, M.R. A ferrocene/imprinted polymer nanomaterial-modified carbon paste electrode as a new generation of gate effect-based voltammetric sensor. New J. Chem. 2018, 42, 4719-4727. [CrossRef]

24. Long, Y.T.; Li, C.Z.; Sutherland, T.C.; Chahma, M.; Lee, J.S.; Kraatz, H.B. A comparison of electron-transfer rates of ferrocenoyl-linked DNA. J. Am. Chem. Soc. 2003, 125, 8724-8725. [CrossRef]

25. He, X.P.; Wang, X.W.; Jin, X.P.; Zhou, H.; Shi, X.X.; Chen, G.R.; Long, Y.T. Epimeric Monosaccharide-Quinone Hybrids on Gold Electrodes toward the Electrochemical Probing of Specific Carbohydrate-Protein Recognitions. J. Am. Chem. Soc. 2011, 133, 3649-3657. [CrossRef] [PubMed]

26. Shuai, H.L.; Huang, K.J.; Xing, L.L.; Chen, Y.X. Ultrasensitive electrochemical sensing platform for microRNA based on tungsten oxide-graphene composites coupling with catalyzed hairpin assembly target recycling and enzyme signal amplification. Biosens. Bioelectron. 2016, 86, 337-345. [CrossRef]

27. Han, G.C.; Ferranco, A.; Feng, X.Z.; Chen, Z.C.; Kraatz, H.B. Synthesis, Characterization of Some Ferrocenoyl Cysteine and Histidine Conjugates, and Their Interactions with Some Metal Ions. Eur. J. Inorg. Chem. 2014, 2014, 5337-5347. [CrossRef] 
28. Han, G.C.; Su, X.R.; Hou, J.T.; Ferranco, A.; Feng, X.Z.; Zeng, R.S.; Chen, Z.C.; Kraatz, H.B. Disposable electrochemical sensors for hemoglobin detection based on ferrocenoyl cysteine conjugates modified electrode. Sens. Actuator B Chem. 2019, 282, 130-136. [CrossRef]

29. Balasubramanian, P.; Settu, R.; Chen, S.M.; Chen, T.W.; Sharmila, G. A new electrochemical sensor for highly sensitive and selective detection of nitrite in food samples based on sonochemical synthesized Calcium Ferrite (CaFe2O4) clusters modified screen printed carbon electrode. J. Colloid Interface Sci. 2018, 524, 417-426. [CrossRef]

30. Cao, L.L.; Fang, C.; Zeng, R.S.; Zhao, X.J.; Jiang, Y.R.; Chen, Z.C. Paper-based microfluidic devices for electrochemical immunofiltration analysis of human chorionic gonadotropin. Biosens. Bioelectron. 2017, 92, 87-94. [CrossRef]

31. Cao, L.L.; Fang, C.; Zeng, R.S.; Zhao, X.J.; Zhao, F.J.; Jiang, Y.R.; Chen, Z.C. A disposable paper-based microfluidic immunosensor based on reduced graphene oxide-tetraethylene pentamine/Au nanocomposite decorated carbon screen-printed electrodes. Sens. Actuator B Chem. 2017, 252, 44-54. [CrossRef]

32. Mani, V.; Periasamy, A.P.; Chen, S.M. Highly selective amperometric nitrite sensor based on chemically reduced graphene oxide modified electrode. Electrochem. Commun. 2012, 17, 75-78. [CrossRef]

33. Pham, X.H.; Li, C.A.; Han, K.N.; Huynh-Nguyen, B.C.; Le, T.H.; Ko, E.; Kim, J.H.; Seong, G.H. Electrochemical detection of nitrite using urchin-like palladium nanostructures on carbon nanotube thin film electrodes. Sens. Actuator B Chem. 2014, 193, 815-822. [CrossRef]

34. Zhang, Y.; Nie, J.T.; Wei, H.Y.; Xu, H.T.; Wang, Q.; Cong, Y.Q.; Tao, J.Q.; Zhang, Y.; Chu, L.L.; Zhou, Y.; et al. Electrochemical detection of nitrite ions using $\mathrm{Ag} / \mathrm{Cu} / \mathrm{MWNT}$ nanoclusters electrodeposited on a glassy carbon electrode. Sens. Actuator B Chem. 2018, 258, 1107-1116. [CrossRef]

35. Losada, J.; Armada, M.P.G.; Garcia, E.; Casado, C.M.; Alonso, B. Electrochemical preparation of gold nanoparticles on ferrocenyl-dendrimer film modified electrodes and their application for the electrocatalytic oxidation and amperometric detection of nitrite. J. Electroanal. Chem. 2017, 788, 14-22. [CrossRef]

36. Ning, D.L.; Zhang, H.F.; Zheng, J.B. Electrochemical sensor for sensitive determination of nitrite based on the PAMAM dendrimer-stabilized silver nanoparticles. J. Electroanal. Chem. 2014, 717, 29-33. [CrossRef]

37. Jiang, J.J.; Fan, W.J.; Du, X.Z. Nitrite electrochemical biosensing based on coupled graphene and gold nanoparticles. Biosens. Bioelectron. 2014, 51, 343-348. [CrossRef] 